\title{
Penerapan Ice Breaker dalam Strategi Pembelajaran Berbantu Kartu Pintar Terhadap Hasil Belajar Kelas I
}

\author{
Sonta Asilsa Faisalina \\ SDN Ngarus 02 Pati \\ faisalina.sonta@gmail.com
}

\section{Article History}

accepted 01/11/2020

\begin{abstract}
The purpose of this study was to improve student learning outcomes in thematic learning class I SDN Ngarus 02 Pati. This research is a classroom action research (PTK) which is carried out in three cycles, each cycle consisting of planning, implementation, observation, and reflection stages. The subjects of this study were 32 students in grade I SDN Ngarus 02 Pati for the 2019/2020 academic year. Data collection techniques using observation and tests. Data analysis includes data reduction, data presentation, and drawing conclusions. Research shows that the application of smart card assisted ice breakers can improve learning outcomes in theme 6 Subthemes 2 learning 1 grade 1 students of SDN Ngarus 02 Pati for the 2019/2020 school year as evidenced by the percentage of learning outcomes completeness in pre-cycle by $25 \%$ to $75 \%$ in cycle I and becomes $93 \%$ in cycle II.
\end{abstract}

Keywords: ice breaker, smart cards, learning outcomes

\section{Abstrak}

Tujuan penelitian ini adalah meningkatkan hasil belajar siswa pada pembelajaran tematik kelas I SDN Ngarus 02 Pati. Penelitian ini merupakan penelitian tindakan kelas (PTK) yang dilaksanakan dalam tiga siklus, setiap siklus terdiri dari tahap perencanaan, pelaksanaan, observasi, dan refleksi. Subjek penelitian ini adalah peserta didik kelas I SDN Ngarus 02 Pati tahun pelajaran 2019/2020 yang berjumlah 32peserta didik. Teknik pengumpulan data menggunakan observasi dan tes. Analisis data meliputi reduksi data, penyajian data, dan penarikan kesimpulan. Penelitian menunjukkan bahwa penerapan ice breaker berbantu kartu pintar dapat meningkatkan hasil belajar tema 6 subtema 2 pembelajaran 1 siswa kelas 1 SDN Ngarus 02 Pati tahun pelajaran 2019/2020 yang dibuktikan dengan persentase ketuntasan hasil belajar pada pra siklus sebesar $25 \%$ menjadi $75 \%$ pada siklus I dan menjadi $93 \%$ pada siklus II. Kata kunci: ice breaker, kartu pintar, hasil belajar

Social, Humanities, and Education Studies (SHEs): Conference Series https://jurnal.uns.ac.id/shes 
SHEs: Conference Series 3 (3) (2020) $360-365$

\section{PENDAHULUAN}

Setiap anak mempunyai kemampuan dan perkembangan yang berbeda-beda dalam menyerap suatu materi. Oleh karena itu guru dalam mengajarkan suatu materi haruslah menggunakan metode, pendekatan dan media yang bervariasi agar tercapainya tujuan pembelajaran.

Pada kondisi awal kenyataannya dilihat dari daftar nilai yang terdapat di kelas I SDN Ngarus 02 pada pembelajaran Tematik Tema 6 Lingkungan Bersih, Sehat dan Asri Subtema 2 Lingkungan Sekitar Rumahku yang difokuskan Kompetensi Dasar 3.4 Mengidentifikasi bentuk kerjasama dalam keberagaman di rumah untuk mata pelajaran PKn, Kompetensi Dasar 3.8 Merinci ungkapan penyampaian terima kasih, permintaan maaf, tolong, dan pemberian pujian, ajakan, pemberitahuan, perintah dan petunjuk kepada orang lain dengan menggunakan bahasa yang santun secara lisan dan tulisan yang dapat dibantu dengan kosakata bahasa daerah untuk mata pelajaran Bahasa Indonesia, Kompetensi Dasar 3.3 Mengenal gerakan anggota tubuh melalui tari pada Mata pelajaran Seni Budaya dan Prakarya masih rendah. Dari 32 siswa, hanya 11 anak yang berhasil tuntas dalam pembelajaran tematik tersebut. Sedangkan hasil persentasenya adalah $34 \%$ siswa saja yang mencapai KKM 75.

Adapun faktor penyebabnya diantaranya adalah pendidik mengajarkan pembelajaran tematik dengan cara klasikal sehingga kurang menarik minat dan perhatian siswa, seluruh proses pebelajaran masih diwarnai pada penekanan aspek pengetahuan dan masih sedikit yang mengacu pada keterlibatan peserta didik dalam proses belajar itu sendiri, dan jumlah siswa yang terlalu banyak dalam satu kelas sehingga pembelajaran kurang efektif, serta pendidik kurang bervariasi dalam penggunaan metode dan media yang tepat.

Untuk meningkatkan kemampuan dan hasil belajar siswa dalam pembelajaran tematik, maka peneliti memanfaatkan strategi pemebelajaran Ice Breaker, yaitu suatu strategi pembelajaran yang pada intinya menekankan pada pembelajaran yang menyenangkan, kreatif dan tidak membosankan. Kala semua itu tidak tercapai, guru harus menggganti strategi dengan menggunakan alat bantu kartu pintar sehingga membuat pembelajaran lebih efektif dan berorientasi pada tujuan. Dengan menggabungkan strategi pembelajaran Ice Breaker dengan berbantu Kartu Pintar, diharapkan dapat meningkatkan hasil belajar siswa dalam mempelajari materi Tematik, khususnya Tema 6 Lingkungan Bersih, Sehat dan Asri, Subtema 2 Lingkungan Sekitar Rumahku, yang difokuskan pada Kompetensi Dasar 3.4 Mengidentifikasi bentuk kerjasama dalam keberagaman di rumah untuk mata pelajaran PKn, Kompetensi Dasar 3.8 Merinci ungkapan penyampaian terima kasih, permintaan maaf, tolong, dan pemberian pujian, ajakan, pemberitahuan, perintah dan petunjuk kepada orang lain dengan menggunakan bahasa yang santun secara lisan dan tulisan yang dapat dibantu dengan kosakata bahasa daerah untuk mata pelajaran Bahasa Indonesia, Kompetensi Dasar 3.3 Mengenal gerakan anggota tubuh melalui tari pada Mata pelajaran Seni Budaya dan Prakarya.

Media pembelajaran kartu pintar dirancang peneliti dalam bentuk kartu. Media kartu pintar dirancang untuk membantu siswa dalam proses berbagai informasi. Media ini berisi berbagai materi yang ada pada Tema 6 Subtema 2 Pembelajaran 1.

Media Kartu Pintar juga dapat memberikan dorongan kepada peserta didik untuk bekerja lebih keras dan berhati-hati dalam belajar, membangun budaya nilai mutu pekerjaan dalam sekolah secara signifikan, serta dapat meningkatkan daya tarik siswa terhadap pembelajaran.

Banyak tuntutan yang harus dilakukan guru dalam memberikan pembelajaran yang tidak membosankan, dengan menggabungkan strategi pembelajaran Ice Breaker dengan berbantu Kartu Pintar, diharapkan meningkatkan hasil belajar siswa sesuai tujuan yang diinginkan peneliti. 
SHEs: Conference Series 3 (3) (2020) 360 - 365

Mengingat pentingnya kemampuan pemahaman pembelajaran tematik pada siswa kelas I sekolah dasar, akan tetapi berdasarkan observasi yang dilakukan peneliti di SDN Ngarus 02, sebagian besar siswa kurang memahami pembelajaran tematik tersebut.

Peneliti tertarik melakukan Penelitian Tindakan Kelas (PTK) untuk mencari solusi mengatasi masalah pembelajaran tematik yang kurang menyenangkan yang pada akhirnya terkait dengan hasil belajar siswa.

Adapun metode yang dapat digunakan untuk menyelesaikan masalah ini dan memberikan variasi pembelajaran yaitu metode ceramah, diskusi, pemberian tugas, demonstrasi, tanya jawab, permainan dengan ice breaking melalui dukungan media kartu pintar.

Adapaun rumusan masalah dalam penelitian ini adalah sebagai berikut:

1. "Apakah pembelajaran Tematik Tema 6 Subtema 2 Pembelajaran 1 dengan penerapan Ice Breaker dalam Strategi Pembelajaran berbantu Kartu Pintar dapat meningkatkan hasil belajar ?"

2. "Bagaimanakah langkah-langkah penerapan Ice Breaker dalam Strategi Pembelajaran dengan berbantu Kartu Pintar dalam meningkatkan hasil belajar siswa kelas I SDN Ngarus 02 mengenai Pembelajaran Tematik Tema 6 Subtema 2 Pembelajaran 1?"

Adapun tujuan penelitian ini adalah sebagai berikut :

1. Mendeskripsikan langkah-langkah penerapan Ice Breaker dalam strategi pembelajaran dengan berbantu Kartu Pintar.

2. Mengetahui peningkatan hasil belajar siswa melalui penerapan Ice Breaker dalam Strategi Pembelajaran dengan berbantu Kartu Pintar pada siswa kelas I SDN Ngarus 02 mengenai pembelajaran tematik tema 6 subtema 2 pembelajaran 1.

Berdasarkan uraian diatas, penulisakan mencoba melakukan penelitian dengan

judul "Penerapan Ice Breaker dalam Strategi Pembelajaran Berbantu Kartu Pintar Terhadap Hasil Belajar Tema 6 Subtema 2 Pembelajaran 1 Siswa Kelas 1 SDN Ngarus 02 Tahun Pelajaran 2019/2020".

\section{METODE}

Penelitian ini merupakan penelitian tindakan kelas (PTK) kolaboratif yang dilaksanakan dalam tiga siklus, setiap siklus terdiri dari tahap perencanaan, pelaksanaan, observasi, dan refleksi. Subjek penelitian ini adalah peserta didik kelas I SDN Ngarus 02 Pati Tahun Pelajaran 2019/2020 yang berjumlah 32 peserta didik.

Waktu perbaikan pembelajaran pada bulan Januari - Februari 2020 yaitu Pra siklus dilaksanakan pada Rabu tanggal 29 Januari 2020, Siklus I dilaksanakan pada hari Rabu tanggal 05 Februari 2020 dan Siklus II dilaksanakan pada hari Rabu tanggal 12 Februari 2020.

Data yang dianalisis berupa data kuantitatif yaitu hasil belajar tematik peserta didik. Teknik pengumpulan data menggunakan observasi dan tes.. Analisis data meliputi reduksi data, penyajian data, dan penarikan kesimpulan.

\section{HASIL DAN PEMBAHASAN}

Penelitian tindakan kelas ini penulis lakukan di SDN Ngarus 02 Kecamatan Pati Kabupaten Pati pada siswa kelas I dengan materi Tema 6 (Lingkungan Bersih, Sehat dan Asri) Subtema 2 (Lingkungan Sekitar Rumahku) yang difokuskan Kompetensi Dasar 3.4 yaitu Mengidentifikasi bentuk kerjasama dalam keberagaman di rumah untuk mata pelajaran PKn, Kompetensi Dasar 3.8 yaitu Merinci ungkapan penyampaian terima kasih, permintaan maaf, tolong, dan pemberian pujian, ajakan, pemberitahuan, 
perintah dan petunjuk kepada orang lain dengan menggunakan bahasa yang santun secara lisan dan tulisan yang dapat dibantu dengan kosakata bahasa daerah untuk mata pelajaran Bahasa Indonesia, Kompetensi Dasar 3.3 yaitun Mengenal gerakan anggota tubuh melalui tari pada Mata pelajaran Seni Budaya dan Prakarya.

Penelitian ini dibantu teman supervisor 2 dalam mengumpulkan hasil observasi terhadap guru dan siswa serta hasil nilai formatif siswa untuk dilakukan analisis. Penelitian ini dilakukan dalam 3 tahapan, tahapan pertama adalah tahap pra siklus, tahap kedua adalah tahap siklus I dan tahap ketiga adalah tahap siklus II.

Adapun indikator pencapaian tiap siklus sebagai berikut:

1. Memberi contoh bentuk-bentuk kerjasama dalam keberagaman di rumah.

2. Menyebutkan ungkapan ajakan kepada orang lain dengan menggunakan bahasa santun.

3. Mengidentifikasi kalimat perintah dalam sebuah lagu dengan bahasa santun.

4. Menjelaskan macam-macam gerakan anggota tubuh mengenai membersihkan lingkungan rumah melalui tari.

Tabel 1. Hasil analisis kemampuan siswa pada pra siklus, siklus I, dan siklus II

\begin{tabular}{lllll} 
No & Uraian & Pra Siklus & Siklus I & Siklus II \\
\hline 1. & Nilai Rata-rata & 57 & 70 & 77 \\
2. & Nilai Tertinggi & 80 & 80 & 100 \\
3. & Nilai Terendah & 40 & 60 & 60 \\
4. & Kriteria Ketuntasan Minimal & 75 & 70 & 70 \\
5. & Siswa Tuntas & 7 & 25 & 26 \\
6. & Persentase Ketuntasan & $25 \%$ & $75 \%$ & $93 \%$ \\
7. & Siswa Belum Tuntas & 25 & 8 & 2 \\
8. & Persentase Ketidak tuntasan & $75 \%$ & $25 \%$ & $7 \%$ \\
\hline
\end{tabular}

Data yang terkumpul pada siklus I pertama berupa lembar pengamatan penguasaan indikator pencapaian kompetensi dasar dengan rata-rata 7,0, data kedua berupa analisis hasil tes formatif dengan rata-rata kelas 70 di bawah kriteria ketuntasan minimal (KKM) untuk mupel Pkn, Bahasa Indonesia, dan SBdP adalah 75, persentase ketuntasan: $75 \%$ artinya dari 32 siswa yang tuntas sebanyak 20 siswa saja sedangkan 8 siswa belum tuntas, data ketiga berupa lembar pengamatan karakter gemar membaca dalam kategori kurang dengan rata-rata 27.

Berdasarkan data di atas peneliti menyimpulkan bahwa penerapan Ice Breaker dengan media kartu pintar dapat meningkatkan hasil belajar tentang materi Kompetensi Dasar 3.4 Mengidentifikasi bentuk kerjasama dalam keberagaman di rumah untuk mata pelajaran PKn, Kompetensi Dasar 3.8 Merinci ungkapan penyampaian terima kasih, permintaan maaf, tolong, dan pemberian pujian, ajakan, pemberitahuan, perintah dan petunjuk kepada orang lain dengan menggunakan bahasa yang santun secara lisan dan tulisan yang dapat dibantu dengan kosakata bahasa daerah untuk mata pelajaran Bahasa Indonesia, Kompetensi Dasar 3.3 Mengenal gerakan anggota tubuh melalui tari pada Mata pelajaran Seni Budaya dan Prakarya dalam pembelajaran tematik dan menjelaskan pengembangan karakter senang membaca dalam pembelajaran tematik tentang materi Perubahan Kenampakan di Bumi dan Benda Langit melalui penerapan Ice Breaker berbantu kartu pintar.

Ice breaker yang direncanakan dalam rancangan pelaksanaan pembelajaran (RPP) memiliki kelebihan, antara lain; ice breaker dapat terpilih secara lebih tepat, baik dalam menyesuaikan materi pembelajaran maupun ketepatan dalam memnuhi prinsipprinsip penggunaan ice breaker dalam pembelajaran; ada kesempatan bagi guru untuk 
belajar terlebih dahulu terhadap ice breaker yang belum dikuasai; ice breaker yang dipersiapkan lebih sinkron dengan strategi pembelajaran yang dipilih guru saat itu; ice breaker terasa lebih menyatu dengan proses pembelajaran yang sedang berlangsung

Data yang terkumpul pada siklus II berupa lembar pengamatan penguasaan indikator pencapaian kompetensi dasar dengan rata-rata 7,7, data kedua berupa analisis hasil tes formatif dengan rata-rata kelas 7,7 di atas kriteria ketuntasan minimal (KKM) 75, persentase ketuntasan: 93\% artinya dari 28 siswa yang tuntas sebanyak 26 siswa saja sedangkan 2 siswa belum tuntas, data ketiga berupa lembar pengamatan karakter gemar membaca dalam kategori kurang dengan rata-rata 28,85.

Berdasarkan data di atas peneliti menyimpulkan bahwa penerapan Ice Breaker dapat meningkatkan hasil belajar siswa melalui penerapan Ice Breaker berbantu kartu pintar dalam pembelajaran Tematik dan menjelaskan pengembangan karakter senang membaca dalam pembelajaran Tematik tentang Kompetensi Dasar 3.4 Mengidentifikasi bentuk kerjasama dalam keberagaman di rumah untuk mata pelajaran PKn, Kompetensi Dasar 3.8 Merinci ungkapan penyampaian terima kasih, permintaan maaf, tolong, dan pemberian pujian, ajakan, pemberitahuan, perintah dan petunjuk kepada orang lain dengan menggunakan bahasa yang santun secara lisan dan tulisan yang dapat dibantu dengan kosakata bahasa daerah untuk mata pelajaran Bahasa Indonesia, Kompetensi Dasar 3.3 Mengenal gerakan anggota tubuh melalui tari pada Mata pelajaran Seni Budaya dan Prakarya melalui penerapan Ice Breaker berbantu kartu pintar.

Penggunaan ice breaker dalam proses pembelajaran berlangsung akan memusatkan perhatian siswa kembali, memberikan semangat baru pada saat siswa mencapai titik jenuh, mengalihkan perhatian terhadap fokus materi pelajaran yang berbeda.

Ice breaker adalah peralihan situasi dari yang membosankan, membuat mengantuk, menjenuhkan, dan tegang menjadi rileks, bersemangat, tidak membuat mengantuk, serta ada perhatian dan ada rasa senang untuk mendengarkan atau melihat orang yag berbicara di depan kelas atau ruangan pertemuan (Soenarno, 2005: 1)

Tabel 2. data perkembangan karakter gemar membaca pada prasiklus, siklus I, dan siklus II.

\begin{tabular}{lllll}
\hline No & Keterangan & Pra Siklus & Siklus I & Siklus II \\
\hline 1. & Rata-rata penguasaan karakter gemar & 25 & 27 & 28 \\
& membaca & & & \\
2. & Skor Penguasaan Indikator tertinggi & 28 & 28 & 32 \\
3. & Skor Penguasaan Indikator terendah & 24 & 24 & 24 \\
\hline
\end{tabular}

Adapun karakter gemar membaca indikatornya sebagai berikut:

1) Mencatat (8)

2) Mengamati atau membaca (8)

3) Melaporkan atau membaca hasil pengamatan (8)

\section{SIMPULAN}

Berdasarkan temuan Siklus I dan Siklus II penelitian ini dapat disimpulkan bahwa:

Penerapan Ice Breaker berbantu kartu pintar dapat meningkatkan hasil belajar siswa tentang materi Perubahan Kenampakan di Bumi dan Benda Langit. Sebagai indikasinya terjadi peningkatan hasil belajar siswa yang ditunjukkan dengan perolehan rata-rata nilai-nilai formatif siswa dari pra siklus 55, siklus I 70 dan siklus II 77 terjadi peningkatan rata-rata sebesar 22 . Sedangkan ketuntasan belajar pada pra siklus $25 \%$, siklus I 75\%, siklus II 93\% terjadi peningkatan sebesar 70\%.

Penerapan Ice Breaker berbantu kartu pintar dalam pembelajaran tematik Tema 6 Lingkungan Bersih, Sehat dan Asri Subtema 2 Lingkungan Sekitar Rumahku yang 
SHEs: Conference Series 3 (3) (2020) $360-365$

difokuskan Kompetensi Dasar 3.4 Mengidentifikasi bentuk kerjasama dalam keberagaman di rumah untuk mata pelajaran PKn, Kompetensi Dasar 3.8 Merinci ungkapan penyampaian terima kasih, permintaan maaf, tolong, dan pemberian pujian, ajakan, pemberitahuan, perintah dan petunjuk kepada orang lain dengan menggunakan bahasa yang santun secara lisan dan tulisan yang dapat dibantu dengan kosakata bahasa daerah untuk mata pelajaran Bahasa Indonesia, Kompetensi Dasar 3.3 Mengenal gerakan anggota tubuh melalui tari pada Mata pelajaran Seni Budaya dan Prakarya secara meyakinkan dapat meningkatkan perkembangan karakter gemar membaca.

\section{DAFTAR PUSTAKA}

Anitah W, Sri. 2008. Strategi Pembelajaran di SD. Jakarta: Universitas Terbuka. Asrori, Mohammad. 2009. Penelitian Tindakan Kelas. Bandung: Wacana Prima. Kokasih, Darma Yoce A. 2009. Menulis Karya Ilmiah. Jakarta: Universitas Nobel Edumedia.

Permendikbud R Nomor 65 Tahun 2013 tentang Standar Proses.

Soenarto, Adi. 2005. Ice breaker Permainan Atraktif Edukatif SD/MI. Yogyakarta: Adi. Susilana, Rudi: Riyana, Cepi. 2009. Media Pembelajaran. Bandung: Wacana Prima. Sumiati: Asra.2009. Metode Pembelajaran. Bandung: Wacana Prima.

Sunarto. 2012. Ice Breaker dalam Pembelajaran Aktif. Surakarta: Cakrawala.

Sulistyanto, Heri: Wiyono, Edy. 2008. Ilmu Pengetahuan Alam untuk SD/MI kelas 4. Jakarta: Pusat Perbukuan Nasional.

Tim Penyusun. 2008. Permendiknas. Jakarta: Departemen Pendidikan Nasional. 